Volume 2

Number 1 Secrecy and Intelligence

September 2018

\title{
Ethnographic Research in the U.S. Intelligence Community: Opportunities and Challenges
}

Bridget Nolan

University of Texas at El Paso, bridget.nolan@gmail.com

Follow this and additional works at: https://scholarworks.sjsu.edu/secrecyandsociety

Part of the Defense and Security Studies Commons, and the Work, Economy and Organizations Commons

\section{Recommended Citation}

Nolan, Bridget. 2018. "Ethnographic Research in the U.S. Intelligence Community: Opportunities and Challenges." Secrecy and Society 2(1). https://doi.org/10.31979/ 2377-6188.2018.020105 https://scholarworks.sjsu.edu/secrecyandsociety/vol2/iss1/5

This Special Issue Article is brought to you for free and open access by the School of Information at SJSU ScholarWorks. It has been accepted for inclusion in Secrecy and Society by an authorized administrator of SJSU ScholarWorks. For more information, please contact scholarworks@sjsu.edu.

\section{(c) (1) $9 \odot$}

This work is licensed under a Creative Commons Attribution-Noncommercial-No Derivative Works 4.0 License. 


\title{
Ethnographic Research in the U.S. Intelligence Community: Opportunities and Challenges
}

\author{
Abstract \\ This article considers lessons learned from conducting research inside the intelligence \\ community. Drawing on a year of ethnographic field work and interviews at the National \\ Counterterrorism Center, I show that "boundary personnel"- people who navigate between \\ the worlds of academia and national security - provide value added in the form of tacit \\ knowledge that outside researchers would not be able to deliver. At the same time, these \\ people face delays, challenges to freedom of information, and ethical considerations that \\ are unique to their positions. Despite setbacks, social scientists must continue their \\ engagement with national security organizations to further our understanding of how these \\ powerful institutions operate.
}

\section{Keywords}

Central Intelligence Agency, CIA, counterterrorism, ethnography, Intelligence Community, National Counterterrorism Center, NCTC, organizational culture, sociology, tacit knowledge

\section{Cover Page Footnote}

The author gratefully acknowledges Kathleen Vogel, Rob Johnston, Randall Collins, Melissa Wilde, David Gibson, and the people of the US Intelligence Community who contributed to this research. 


\title{
Ethnographic Research in the U.S. Intelligence Community: Opportunities and Challenges
}

Bridget Rose Nolan

\begin{abstract}
This article considers lessons learned from conducting research inside the intelligence community. Drawing on a year of ethnographic field work and interviews at the National Counterterrorism Center, I show that "boundary personnel"- people who navigate between the worlds of academia and national security - provide value added in the form of tacit knowledge that outside researchers would not be able to deliver. At the same time, these people face delays, challenges to freedom of information, and ethical considerations that are unique to their positions. Despite setbacks, social scientists must continue their engagement with national security organizations to further our understanding of how these powerful institutions operate.
\end{abstract}

\section{Keywords}

Central Intelligence Agency, CIA, counterterrorism, ethnography, Intelligence Community, National Counterterrorism Center, NCTC, organizational culture, sociology, tacit knowledge

The relationship between science and the government has historically been fraught. Scholars have shown that the boundary between the two domains is not static but rather dynamic and flexible, drawn and redrawn in historically contingent and sometimes ambiguous ways (Gieryn 1983;

Dennis 1999; Berling and Bueger 2013; Wellerstein 2008). Research on scientists in STEM fields pays particular attention to the difficulty of 
Secrecy and Society, Vol. 2, No. 1 [2018], Art. 5

negotiating the tension between academic freedom and national security interests. For instance, Evans and Valdivia (2012) discuss the U.S. government's intervention in scientists' publication of the methods used to replicate the H5N1 bird flu virus over bioterrorism concerns; Russell and Webster (2005) discuss a similar controversy over the genetic sequencing of the 1918 flu virus. Others show that the development and deployment of powerful weapons over the last century centralized science and technology as security concerns for the U.S. government (e.g., Vogel, Balmer, Evans, Kroener, Matsumoto, and Rappert 2017; Bussolini 2011). Nuclear weapons in particular have been a consistent focal point, as have the social organization of their development at Los Alamos National Laboratory and Lawrence Livermore National Laboratory (e.g., Gusterson 1996; Rhodes 1986; Teller 1993; Bussolini 2011; Masco 2006).

The emphasis in this literature is understandably on natural sciences, math, and engineering, so for the most part it overlooks how social scientists negotiate similar tensions when working on issues related to national security, intelligence, and the military. In addition, research exploring the relationship between science and the government focuses almost exclusively on scientists who do research for the U.S. government, rather than those who do research on it. Finally, the contested material in this research is information, not personnel: scientists and government officials, often seeing themselves as occupying separate spheres, negotiate a blurry space in which 
Nolan: Ethnographic Research in the U.S. Intelligence Community

both entities lay claim to some scientific finding, method, or product. The social positions of the people themselves are not contested in the literature; the spheres seem to blur when committees are formed to negotiate acceptable information use (Evans and Valdivia 2012), but there is no discussion of the ways in which individual researchers may navigate both spaces. This article looks at the challenges and opportunities presented when social scientists themselves blur the boundary between government work and academia. How does their negotiation of this interstitial space affect the research process? What kinds of insights can the security clearance yield for an academic researcher, and - perhaps more importantly - what are its limitations? How might these accesses shape social scientists, and what are the longer-term implications for scholarship as a result of their experiences inside the intelligence community? Finally, what can research inside the U.S. intelligence community teach us about its people, analytic practices, and organizational culture that social scientists would not be able to learn from the outside? ${ }^{1}$

1 Methods: Ethnography is the descriptive documentation of a living culture. It usually combines a number of approaches, such as participant-observation, interview, and artifact analysis, to present a detailed picture of the culture of interest. It is generally qualitative and designed to present the view of the study subjects as understood from the researcher's own perspective. Ethnographic methods originally emerged in anthropology, but have since been adopted by other social sciences, including sociology. The classical view is that ethnography requires the researcher to spend significant time (years, ideally) living among the people they are studying, but sociologists have had success in using ethnography to study cultures in work places, schools, or other organizational locations without actually living with the people they are studying. My research fits into this latter application of ethnographic methods. I worked as a counterterrorism analyst for the Central Intelligence Agency (CIA) between 2007 and 2011. During my time there, I sought and received permission to conduct an ethnography of the National Counterterrorism Center (NCTC), which is the organization that was created after 9/11 to address the 9/11 Commission Report's finding that 
Secrecy and Society, Vol. 2, No. 1 [2018], Art. 5

\section{Tacit Knowledge}

In thinking of the ways in which people may blur the space between

academia and security organizations, it is useful to deploy the concept of boundary objects, "those objects that both inhabit several communities of practice and satisfy the informational requirements of each" (Bowker and Starr 1999, 297). What we might call "boundary personnel" instead of "boundary objects" have similar features. I argue that social scientists wishing to study how the intelligence community (IC) works cannot get a comprehensive picture of what the organizations are like without spending

intelligence agencies were not sharing information the way they could or should. NCTC was created to house officers from all around the IC under one roof, with the hopes that working alongside representatives from other agencies would encourage analysts to share information. During the course of my research, I wanted to explore whether and how that information sharing occurs. As a sociologist, I was interested in learning about the small, day-to-day interactions that comprise the life of the analyst, as well as the larger organizational dynamics that accomplish intelligence work. I conducted 20 indepth interviews between August and December of 2010. I knew most of the participants personally, but a few people I did not know got in touch with me after hearing about my study and asked to participate. I aimed to get a relatively diverse sample with regard to the analysts' home agencies, to get as many perspectives as possible. Official demographic information was not available, but my perception is that the population of analysts in the wider IC is not particularly diverse on measures of race, gender, and age, so there is some, but not much, variation on these measures in my interview sample. The average age of the interview participants was 31.8 years, with a range of 24 to 47 and a median of 31.5. All but three of the participants identified as white; 13 identified as female and 7 as male. The average amount of time served at NCTC was 2.48 years, with a range of four months to six years, and a median of two years. The average amount of time served in the federal government was 7.7 years, with a range of 2 to 15 years, and a median of 7.5 years. Thirteen of the participants had at least one graduate-level degree, usually a master's degree. Thirteen of the participants claimed CIA as their home organization; seven of the longer-serving participants claimed more than one home organization over the course of their careers. Drawing from my observations and experiences, my sample reflects the analyst population writ large, with the possible exception of the gender breakdown. (My sense was that most analysts were male, but again I cannot be sure, because official demographics are not available; in any case, there is still very much an "old boys' club" feel to both CIA and NCTC, which analysts reported and with which my own experience was commensurate [e.g., Jones 2016].) 
time as a practitioner. The primary reason for this is that intelligence work relies heavily on tacit knowledge - knowledge that, contrary to explicit knowledge, cannot be and/or has not been effectively stored or transferred by impersonal means such as verbal or written instructions (MacKenzie and Spinardi 1995).

The prevalence of tacit knowledge in professions is not new or unique to intelligence work - it is an important reason why many occupations have historically relied on the apprenticeship model - but the combination of the primacy of tacit knowledge with the secrecy that shrouds the IC means that spending time as a practitioner is absolutely crucial for understanding this work. Boundary personnel are especially important for this research because tacit knowledge is embodied (MacKenzie and Spinardi 1995). Even in security areas that may at first seem to rely more heavily on explicit knowledge - MacKenzie and Spinari (1995), for instance, focus on the production and reproduction of nuclear weapons - tacit knowledge proves so important that its absence would result in the "uninvention" of the weapons entirely, even in the presence of explicit knowledge in the form of lab notebooks, computer programs, and general physics expertise. For intelligence practitioners, tacit knowledge often takes the form of "judgment": a sense, accumulated in the body over some period of time of having done the job, of what works and what doesn't, of what seems right and what feels wrong. Of course, some of what the CIA does has a hard- 
Secrecy and Society, Vol. 2, No. 1 [2018], Art. 5

science component, but much of the subject matter policymakers want to know about requires even more reliance on tacit knowledge because of the challenges, gaps, and uncertainties involved in collecting and analyzing intelligence.

The sense of judgment conferred by the accumulation of tacit knowledge takes time to develop. As a result, practitioners speak of a "long learning curve" (MacKenzie and Spinardi 1995, 62); with regard to nuclear weapons development, even designers with relevant physics backgrounds take "five years to become useful." My own experience is commensurate; in my dissertation, I wrote the following about my first impressions inside the CIA:

The learning curve was unbelievably steep, not only in the methods of doing the job but also the ways in which people exchanged mere pleasantries. I frequently found myself understanding the words, but not the meaning, of what people said to me, which created a profound sense of culture shock and made the adjustment incredibly difficult. This shock was exacerbated by the secrecy in which the job is engulfed; there is no real way to prepare oneself for the first days and weeks of this job. It was as though a curtain were lifted, and all of the people, places, and things behind it came hurtling at me all at once with the force of water from a fire hose. (Nolan 2013, 3)

I was explicitly told in my first weeks inside the IC that I should not expect to get anything done (in the form of publishing classified papers) for at least the first few months, maybe even a year. It can take up to six months to be granted access to some classified systems, and accumulating the tacit knowledge required not only to do quality intelligence analysis but also to navigate routine daily situations simply must be acquired the hard 
way. Many of my colleagues pointed to the organization's reliance on tacit knowledge as one of their greatest sources of overwhelm and frustration. They reported, and my own experience confirmed, that tacit knowledge ranged from relatively small matters, such as figuring out the correct form to complete, to larger matters, such as knowledge of one's own job description or the goals of the larger organization. Part of this confusion at the National Counterterrorism Center (NCTC) stems from the fact that as a fledgling organization, NCTC's predecessor simply adopted many of CIA's bureaucratic procedures. This is confusing for non-CIA personnel at NCTC, but it is also confusing for CIA employees, because it is often unclear which organization is supposed to take responsibility for an action. Some analysts told me that they felt the management sometimes used this lack of clarity between agencies as an excuse not to fund training opportunities or travel expenses. A few excerpts illustrate this idea:

CIA analyst: If there is [frustration at work], it's usually figuring out how you're supposed to do something, what the proper procedure is. It's hard to figure out if it's not written down anywhere. Like travel. The simplest thing like buying a plane ticket is so not intuitive, and you often don't even know to ask. (Nolan 2013, 34)

CIA analyst relatively new to the IC: This place is just so weird, because the people here seem to assume things that are not at all intuitive, and then they get mad when you haven't come to those conclusions yourself. Like, when I first started here, they were doing some construction and there were fewer parking spaces, so they instituted this valet parking system. But it wasn't like a valet in the real world where you pull up and hand the attendant the key or whatever. You were supposed to just know that you had to leave your car key on the left rear tire, in case the valet had to move your car. Even on your first day without having met anyone you were somehow 
supposed to know this. Well, I'd been working there for months and I didn't know it. Why would you assume something like that? How does that make intuitive sense? So I took my keys with me, and it turns out I was blocking in one of the higher-ups who needed to get out to go to a briefing, and they sent this system-wide flash alert to everyone's computer screen about my car, and it was just so embarrassing, but like, how was I supposed to know? And how was I supposed to know that I didn't even know how to park my car? Stuff like that makes you start second-guessing everything you took for granted before. (Nolan 2013, 34)

Several analysts I talked to (and my own experience) corroborated this idea of not only not knowing something, but not even knowing what to know or what to ask, which contributed to this overall feeling of chaos. In a larger, more general sense, many of my colleagues told me that they often were not really sure what their jobs were, and they felt that they had very little understanding of what other people in the organization do, even those in the same analytic group:

CIA analyst: NCTC is really focused on getting tools and training its people but-there's all this talk about loose threads, like the Pursuit cell [the group created after the 2009 failed Christmas Day bombing to follow so-called "loose threads"], and I don't really know what that means. I don't even know what I'm doing on a day to day basis. We're fighting the War on Terror. What does that actually mean? How do you specifically go about that day to day? Like, when we were fighting the Cold War, we were more sure then, I think. There was a country that we could point to and we knew we were fighting. Now it's like, networks, there don't seem to be countries anymore with this, and it's really hard to know what winning this war would look like. (Nolan 2013, 35)

CIA analyst: Over the time that I worked in the IC, I was always amazed at how little people knew about other people's jobs. ... You've been there three and a half years, and you're telling me that you don't know anything outside of REM [analytic group]. I don't know anything about REM. And we're just within one area. Within LX [the Liberty Crossing building, where NCTC is located], there are floors dedicated 
to the FBI or the CIA. Do you know who even works there? Have you ever been there? It's not like HQ where there are areas you can't get into. But LX isn't like that. So I mean, LX is like Spaceballs. Do you know the scene I'm talking about? It's like the captain of the ship, and he's talking to the guy on the screen, and he's like, WTF, we can't hear you, and it's like, they just come around to the other side of the screen. It's like a SVTC [secure video teleconference], you realize half the people in the SVTC are actually in the building and we're wasting 15 minutes trying to get the damn thing to work. I wouldn't be derogatory toward NCTC though. I would think about it as like, the incredible challenges that NCTC has to navigate in order to integrate the way it wants to, with something that's fundamentally designed not to be integrated. (Nolan 2013, 35)

This phenomenon is not uncommon in large organizations; Vaughan $(1996,250)$ states that as organizations grow, the actions of the people that comprise them become less easily observable. Vaughan also says that secrecy is a fundamental feature of any organization, not just organizations like the CIA that specifically require secrecy to protect sources and methods. Increased hierarchy, bureaucratization, and specialized knowledge create social distance among employees, making it difficult to understand fully what another part of the organization does, and so this finding may not seem remarkable in a government organization like NCTC. But the added dimension of secrecy as a specific function of the organization adds complexity to these issues, and as Vogel et al. (2017) remind us, the unique operation of secrecy in security organizations, as opposed to private life or the commercial sector, means these organizations are worthy of special consideration. 
Secrecy and Society, Vol. 2, No. 1 [2018], Art. 5

These examples barely scratch the surface of the many ways in which intelligence work relies on tacit knowledge. Creating written products - the primary task for intelligence analysts - is frequently described as an "art," which connotes the importance of subjective judgment and creativity (e.g., Hasler 2010; Crumpton 2013). Even more often, intelligence work is characterized as "tradecraft," a "catchall for the often-idiosyncratic methods and techniques required to perform [intelligence] analysis," defined as "practiced skill in a trade or art" that "purposefully implies a mysterious process learned only by the initiated and acquired only through the elaborate rituals of professional indoctrination" (Johnston 2005, 17-18). Echoing MacKenzie and Spinardi's (1995) finding that judgment is a collective phenomenon rather than an individual one, analytic papers in the IC are considered "community" products; the paper does not bear the name of the individual author, but rather the seal of the institution for which the author works. The CIA at least recognizes that tacit knowledge is embodied; some CIA-sponsored documents explicitly talk about the loss of institutional memory due to attrition (e.g., Johnston 2005), and during my time there, people in positions of power talked about the need to preserve this kind of embodied information by strengthening mentoring programs and generating "lessons learned"-type documents.

All of this speaks to the benefits - indeed, the necessity - of having an intelligence practitioner with the proper academic training conduct research 
on the intelligence community. Depending on their research questions, academics with no personal experience on the "inside" may find their lack of access to be an insurmountable challenge; the practitioner's embodied sense of the profession is thus the greatest opportunity afforded by their access.

\section{Socialization and the Security Clearance}

"Insider" status presents challenges in addition to its opportunities. Getting a security clearance to work at the CIA is a long, arduous, sometimes-harrowing process that requires the applicant to open their lives entirely to a faceless bureaucracy with no guaranteed payoff. I was required to have a background check, during which the government talked to family members, close friends, and neighbors about my personal character and lifestyle. I submitted to days of physical and psychological testing, including an eight-hour polygraph exam. I did all of this voluntarily, but with no idea of what kinds of information was waiting for me once I had a Top Secret clearance. There is, by definition, no way to know until you know. This access unquestionably shaped me as a person and as a social scientist; I distinctly recall a colleague's comments in my first weeks at the Agency that they could tell by the look on my face that I had been "read in"-that is, that I had learned Top Secret information. I related to Masco's (2010: 441) discussion of secrecy's "distorting effects" and Daniel Ellsberg's (2002) reflections on the psychological effects of access to classified information in 
Secrecy and Society, Vol. 2, No. 1 [2018], Art. 5

his autobiography. That access has static and dynamic elements; once you know something, you know it, but the maintenance of that information requires obfuscation, occasional lying, and many kinds of keeping track, all of which is invisible labor that takes a toll.

Moreover, the onboarding processes for intelligence practitioners vary by agency. My research shows that there is a persistent status hierarchy among the intelligence agencies and that the CIA is at the top of that hierarchy, even after the post-9/11 restructuring of the U.S. Intelligence Community. It is therefore impossible to present oneself as both an insider and as a neutral researcher. As a researcher, I had the bias-mitigating advantage of not having physically worked at CIA Headquarters for very long before I started working at the National Counterterrorism Center, but I was still a CIA person, and was viewed and treated as such during my time in the IC. I therefore tried as much as possible to foreground the experiences and stories of others, and included my own only when they were also corroborated by my colleagues.

Still, insiders conducting any kind of fieldwork must guard against what is sometimes called "going native" (Hammersley and Atkinson 1995, 110 ) in social science research and "clientism" in the intelligence community (Lowenthal 2014, 163): the tendency to become so immersed in the target population that the researcher defends or apologizes for that population instead of analyzing it more objectively. All ethnographers must prioritize 
the protection of their subjects' identities, but research inside the IC ups the ante on this. Vogel et al. (2017) highlight this challenge, suggesting that concerns about protecting information and the identities of colleagues inside the IC may result in the researcher's actively and selectively deleting important details from the story they tell. Given that writing an ethnography is already a process that shapes rather than reflects the population of interest (Hammersley and Atkinson 1995), the added security concerns surrounding identity protection constitute a further challenge to the research process. I certainly made these kinds of choices, both consciously and-I am sure-unconsciously. There were many incredibly rich details and interactions that I could not document because of the highly sensitive circumstances in which they occurred, and there were times when I probably could have written about certain situations but chose not to in order to protect my colleagues. I felt that these choices were necessary for me to uphold both my oath of office and the ethics of field work, but I am cognizant that these choices also necessarily affect both the research process and the final product.

\section{Ethical Concerns}

Among the social sciences, anthropology has the longest and most complicated history with the U.S. military and intelligence services. The U.S. government has employed anthropologists ostensibly in pursuit of 
Secrecy and Society, Vol. 2, No. 1 [2018], Art. 5

"sociocultural expertise" (Kusiak 2008), but controversy over its deployment in programs such as the Human Terrain System and abuses during the Cold War, coupled with the discipline's colonialist history, have led to calls within the field to examine its relationship with the U.S. government (American Anthropological Association 2007). These concerns over "weaponizing anthropology" (Price 2011) have resulted in recommendations from the American Anthropological Association to revise its Code of Ethics to achieve more granularity on issues of secrecy as a condition for funding, informed consent, and "politically distasteful" vs. "ethically problematic" activities (American Anthropological Association 2007, 25). The report does make distinctions among types of research projects, noting that policy work and organizational studies are less ethically risky than operational roles in which anthropologists are asked to provide front-line expertise to support military commanders in the field (American Anthropological Association 2007, 12-

13). These recommendations underscore the key difference in conducting research for the U.S. military and intelligence services rather than on them (American Anthropological Association 2007, 16).

Rob Johnston's (2005) work on CIA analytic culture is the best example of anthropological research on the U.S. intelligence community. Johnston himself may be considered "boundary personnel," since his work is available in open sources, and he has worked both in academia and the IC. But because his work was sponsored by the CIA - he was hired by the CIA's 
Center for the Study of Intelligence - this research on the CIA was also for it at the same time, which is muddier territory for the AAA's positions on this work. I hasten to add that I do not think Johnston's work is ethically questionable in any way; I merely highlight the difficulty of navigating these two spheres for any researcher.

Sociology does not have the same colonial history as anthropology; I am also the only sociologist I know of who has attempted ethnographic research on the IC, so the ethical challenges I faced are confined to my own projects rather than rising to the level of discipline-wide ethical contemplation, as anthropology has required. Although my work in many ways was a straightforward workplace ethnography, secrecy and security concerns created additional dilemmas. For instance, the American Sociological Association's Code of Ethics requires that informed consent be obtained from research participants in a process that "involves oral and/or written consent" (American Sociological Association 1999, section 12.02). I would have preferred to have my interview participants fill out consent forms on paper, but in order to protect their identities, I sought the blessing of my institution's IRB to obtain verbal consent only. Though the Code clearly states that this is permissible, I still had to think through the ethics of less record keeping rather than more. I also had to consider the privacy issuesseparate from security issues - that every workplace ethnographer must face. Obtaining informed consent from interview subjects is one thing, but 
what about ordinary interactions among workers in what they rightly assume is private space? I was able to make the case to my institution's IRB that my research met the two criteria for the general informed consent waiver: The research involved no more than minimal risk to the participants, and the research could not practicably be carried out if general informed consent were required (section 12.01). Coupled with the "top cover" of having the Deputy Director of the National Counterterrorism Center give me written permission to do the project, I satisfied these ethical obligations, but not without adding months to my timeline.

These days, the use of recording technology eases many ethnographer concerns. The use of video/audio recording (with the subjects' informed consent) can allow the researcher to focus more on what is going on in the moment without also having to worry about recording. At the CIA and at NCTC, though, recording equipment of any kind is prohibited, which meant I could not bring in a tape recorder, cell phone, camera, or laptop. This is understandable for preventing the disclosure of classified information, but it made conducting interviews quite difficult - I had to take handwritten notes, and I was only able to get verbatim quotes if the participant was willing to wait for me to write more than jottings or repeat what they'd said, which often disrupted the flow of the conversation and took up valuable interview time. Even when the interviews took place outside of the office, I still did not want to record my colleagues in the interest of protecting their identities, 
though being able to use a laptop outside of work did allow the conversations to flow a bit better and faster. Although I knew I had no choice about recording, I did then have to face ethical dilemmas about how I wanted to represent my colleagues' experiences textually. I made careful choices about how I was going to use quotation marks to indicate verbatim comments when, without a recording, I could never be completely sure they were verbatim. Even when I reviewed turns of phrase with my colleagues and asked them to confirm that I was representing their words fairly, I necessarily lost some of the first-take freshness and spontaneity recordings afford.

None of these dilemmas rise to the level other social scientists have faced in their work on and for the IC and the military, but it is important that each ethical dilemma be taken seriously and navigated successfully in order for the work to maintain its integrity.

\section{Longer-Term Issues for Scholarship}

There can be no doubt that the primary challenge presented to boundary personnel stems from the non-disclosure agreement employees with security clearances are required to sign. This contract requires the signatory's surrender of some First Amendment rights. From the moment of signing, whether the employee works in national security for a day or for thirty years, they must submit all writing related to their job to a board that 
will review it to determine whether it contains classified information. At the CIA, that body is the Publications Review Board (PRB); if other entities, such as the Office of the Director of National Intelligence (ODNI) have a stake in the material, they also weigh in. This requirement extends beyond traditional publication outlets such as books or articles to include blog posts, opinion pieces, tweets, Facebook posts, resumes, speeches, and more, and the material must be cleared before it can be shared with editors, colleagues, advisers, friends, or anyone without a clearance for that material (Central Intelligence Agency 2016). The need to protect against the disclosure of classified information is of course undeniable, and signatories enter into this contractual obligation freely.

This requirement begins to present challenges to scholarship when classification standards become unclear. Information is classified when it is determined that its disclosure would cause some degree of damage to national security; the difference among Confidential, Secret, and Top Secret information is that its disclosure would respectively cause "damage," "serious damage," and "exceptionally grave damage" to national security (The White House Executive 2009). Very little guidance is available to help determine the differences among these phrases, which leads to overclassification for practitioners (e.g., Ellington 2011) and uncertainty for would-be writers and publishers. Materials available in the public domain are 
sometimes redacted anyway (Masco 2010), and approaches to releasing classified or sensitive information seem to vary by agency (Masco 2010).

I argue that information review also varies within agencies. For instance, when I revised a chapter of my dissertation, I included a few sentences that the PRB had previously approved, but they were returned to me this time redacted in the following way:

[CIA applicants] must endure days of physical and psychological testing, including a harrowing polygraph examination, during which the examiner may to the applicant. My polygraph lasted hours, and while spending most of that time strapped to a tight blood pressure cuff, I

I requested clarification of the new redactions, and included the original approved manuscript from January 2015 to show where the text had previously been cleared. I was told that the redactions were based on "current classification guidance," and that the Board upheld all redactionswith the exception of the word "eight," which I was now allowed to print:

[CIA applicants] must endure days of physical and psychological testing, including a harrowing polygraph examination, during which the examiner may to the applicant. My polygraph lasted eight hours, and while spending most of that time strapped to a tight blood pressure cuff, I

In other words, as of January 2015, I was allowed to say that my polygraph lasted eight hours (and that version of the manuscript remains on the Internet for anyone to see); on November 14, 2017, I was no longer allowed to say the word "eight"; and two days later, on November 16, it was 
allowed again. It is difficult to believe that these changes were based more on objective "current classification guidelines" - and that those guidelines happened to have changed in a two-day period in a way that specifically affected my use of the word "eight" - than on the subjective individual variation introduced by whomever answers the request for review. Does it really matter whether people know my polygraph lasted "hours" or "eight hours"? No, but the principle is the point: As we know from Durkheim, the organizational approach to managing secrets is often more important than the content of those secrets ([1912] 1995). Moreover, the workings of the PRB itself are secretive: Despite my efforts to find out, I still do not know how many people sit on the PRB nor whether its decisions are reached by majority vote or some other procedure. Just as the practice of "science" is not static, but rather a dynamic, iterative process (Gieryn 1983), so too is the production and reproduction of "classification," echoing Vogel et al.'s (2017) point that knowledge more generally is socially constructed at every step along the way.

Other scholars have grappled with similar issues. Aftergood (1999) writes about what he calls "genuine national security secrecy"-in other words, legitimate secrecy - as opposed to "political secrecy" (secrecy maintained for a political advantage) and "bureaucratic secrecy" (20) (the Weberian tendency of bureaucracies to control perception of the organization by restricting information), both of which are illegitimate but nonetheless 
common practices dating back to World War II; Dempsey (1998) has similar qualms. The asymmetrical power relationship between the writer and the state further complicate freedom of speech issues, and indeed the interactions between the PRB and the writer are sites for the performance and reproduction of that asymmetry. Former practitioners-turnedmemoirists perhaps face less career pressure concerning the PRB but are no less beholden to - and often no less frustrated by - its caprices (e.g., Plame 2007; Hayden 2016).

Associating with the IC or the military can also affect the scholar's selfconcept and their relationship with their discipline. Working for the CIA in particular is simultaneously prestigious and stigmatized; the salience of each quality depends heavily on social context, such that the scholar may constantly find themselves navigating which parts of their professional experience to highlight and which to downplay. The AAA report on anthropological engagement with the security and intelligence communities finds that "many" of the anthropologists the committee interviewed felt "disconnected" from the Association (American Anthropological Association $2007,56)$. Some had allowed their professional memberships to lapse, either because they no longer felt it was relevant to their work or because "they felt uncomfortable attending conferences where they would have to explain their involvement ... to a potentially hostile audience" (American Anthropological Association 2007, 56). An academic anthropologist who did 
Secrecy and Society, Vol. 2, No. 1 [2018], Art. 5

contract work for the Department of Defense used the language of "staying in the closet" about his involvement, out of fear of losing friends; another practitioner was called a "fascist" during a session at the AAA annual meeting because of her involvement with the military, and recalled not getting much support from the audience in her defense (American Anthropological Association 2007, 57). I have not encountered that kind of hostility, but I have had people react unfavorably to my affiliation, as when a potential editor rejected my book proposal on the grounds that "this project takes a lot of granted: i.e. that the work of these counter-intelligence agents should be wholly supported" (personal correspondence, 6/27/14). ${ }^{2}$ If other sociologists take issue with my affiliation, it is most likely to be expressed in a way that would make it indistinguishable from the many kinds of rejection academics already face in a hyper-competitive field (for instance, having articles or grant proposals rejected, or not being invited to interview for a job).

The requirement to submit all written work to the PRB also introduces a timing issue for scholars. The longer the manuscript and the more entities that are involved, the longer this review process can take; one must resubmit revisions to the PRB as well, such that the researcher must draft the work on their own, obtain PRB approval before sending the manuscript to colleagues or editors, then go back for further review with the PRB after revisions are complete, then go back for more review if editors or colleagues 2 I choose not to include additional citation information to protect the editor's identity. 
suggest further revisions. The process of publishing in sociology has already come under scrutiny for, among other things, the amount of time it can take to get through review; the requirement to send all written work to the IC every step of the way has the effect of significantly slowing down an already-sluggish process. This can leave the researcher in the position of having done interesting research, but not having much to show for the amount of time that has to pass before it is published - an additional pressure in a supremely difficult job market and tenure process. A practitioner-academic may have published prolifically in classified journals or other forums, but if that work must remain classified, their CV may appear blank. Gusterson $(1999,58)$ addresses this problem - the "death of the author" - among nuclear scientists working at Livermore Laboratory, but the lack of ownership over their government work is an issue with which all practitioners must contend if they intend to negotiate that transition successfully.

Restrictions on writing for former employees means that boundary personnel do not have the same freedoms to respond to critics of their writing or comment on current events in a timely manner. These days, it is not uncommon for academics to have Twitter accounts or personal websites that they use to increase their visibility in their field, but the requirement to send all writing to the PRB results in delays that mitigate the effectiveness of these platforms when used for career-enhancement purposes. 
Longer-term implications for scholarship also depend upon one's status in the IC. If the researcher leaves the IC to pursue academia, they are still beholden to the regulations of the review board but may be unable to gain further access to the population. Thus, if an editor or reviewer raises an issue that would be best addressed with further inquiry-follow-up interviews or more observations - the researcher is likely unable to fulfill this request. If the researcher has remained inside the IC to allow for continued access, they are subject to additional standards of review that may make getting manuscripts out even more difficult than it already is. Although a former employee's writings can only be rejected if the manuscript contains classified information, current employees face additional standards, such as whether the research interferes with the employee's job duties or with U.S. national security interests.

Staying on the inside also means the researcher must continue to deal with the labyrinthine bureaucracy that comprises the U.S. government. On top of the standard delays and inefficiencies, the researcher may be met with resistance from unknown bureaucrats who are not even involved in the research and spend much of their time seemingly spinning their wheels. Thus, there are pros and cons to staying or leaving, but either decision will inevitably result in delayed or stalled projects. On the plus side, having worked in the IC can lend a degree of credibility and value added that cannot be achieved with an outsider perspective, which may offset some of 
the costs of conducting research. There is an argument to be made that the benefits outweigh the costs, but to the extent possible, academics should plan and prepare for these substantial costs when developing their research agendas.

\section{Conclusion}

I have focused primarily on the challenges and opportunities presented to individual scholars - what I've termed "boundary personnel" - as they navigate dual identities as intelligence practitioners and scholars. But it is crucial to remember that this negotiation is taking place in the context of macro-level approaches to notions of secrecy and openness that are constantly shifting in response to and/or in anticipation of geopolitical realities. In the 21st century - and especially post-9/11 - the government has publicized efforts to declassify more material (McDermott 2011), and the official rhetoric has shifted towards the value of increased information sharing and collaboration among the intelligence agencies, from a "need to know" to a "need to share" posture. ${ }^{3}$ At the same time, researchers have seen a contradiction emerge: They argue that this same period has resulted in more classification and restricted access to information from the outside (Ellington 2011; Masco 2010) in what they term the "securocrats' revenge" (Aftergood and Blanton 1999, 457) and the "iron curtain of secrecy" (Ericson

3 This terminology is problematic as it potentially reads as a false dichotomy: Information must always be shared with those with a genuine need to know, although the point of the underlying sentiment is taken. 
2005). These constantly shifting dynamics mean that there can never be a standard approach to this work; scholars must contend with the sense that the sand is always shifting beneath their feet.

Rindzeviciute (2015) has suggested that massive government disclosures can go too far the other way and cause unanticipated harm, such that a "sweet spot" between full secrecy and full transparency may be desirable, if it even makes sense to think in these terms. But it is not in the government's best interest to limit inquiries too much either, because transparency and accountability are essential elements of a democracy. Similarly, it is unwise for boundary personnel to back away entirely and become discouraged by these many challenges. Social scientists - especially those who study organizations and bureaucracies more generally - have an intellectual obligation to engage with the intelligence community and other security institutions, so that we may better understand how these complex seats of power operate. The value added of having practitioners do this work is that their tacit knowledge provides nuance and complexity to a body of scholarship that would otherwise suffer from their absence.

\section{References}

Aftergood, Steven. 1999. "Governmental Secrecy and Knowledge Production: A Survey of Some General Issues." In Secrecy and Knowledge Production. Occasional Paper No. 23, edited by Judith 
Reppy, 17-29. Ithaca, NY: Cornell University Peace Studies Program. http://large.stanford.edu/publications/crime/references/dennis/occasion al-paper23.pdf

Aftergood, Steven, and Tom Blanton. 2009 [1999]. "The Securocrats' Revenge." In Government Secrecy: Classical and Contemporary Readings, edited by Susan Maret and Jan Goldman, 457-59. Westport, CT: Libraries Unlimited.

American Anthropological Association. 2007. Commission on the Engagement of Anthropology with the U.S. Security and Intelligence Communities. Final Report, November 4. http://www. policyarchive.org/handle/10207/20640

American Sociological Association. 1999. "Code of Ethics of the ASA Committee on Professional Ethics." Washington: American Sociological Association. http://www.asanet.org/sites/default/files/code_of_ethics_aug_2017_1 .pdf

Berling, Trine Villumsen, and Christian Bueger. 2013. "Practical Reflexivity and Political Science: Strategies for Relating Scholarship and Political Practice." Political Science and Politics 46, no. 1: 115-19.

Bowker, Geoffrey, and Susan Leigh Starr. 1999. Sorting Things Out: Classification and its Consequences. Cambridge, MA: MIT Press.

Bussolini, Jeffrey. 2011. "Los Alamos as Laboratory for Domestic Security Measures: Nuclear Age Battlefield Transformations and the Ongoing Permutations of Security." Geopolitics 16: 329-58.

Central Intelligence Agency. 2017. "Keeping Secrets Safe: The Publications Review Board." February 2. https://www.cia.gov/aboutcia/publications-review-board

Crumpton, Henry A. 2013. The Art of Intelligence: Lessons from a Life in the CIA's Clandestine Service. New York: Penguin Books. 
Dempsey, James X. 1998. "The CIA and Secrecy." In A Culture of Secrecy: The Government Versus the People's Right to Know, edited by Athan G. Theoharis, 37-59. Lawrence: The University Press of Kansas.

Dennis, Michael Aaron. 1999. "Secrecy and Science Revisited: From Politics to Historical Practice and Back." In Secrecy and Knowledge Production. Occasional Paper No. 23, edited by Judith Reppy, 1-16. Ithaca, NY: Cornell University Peace Studies Program. http://large.stanford.edu/publications/crime/references/dennis/occasion al-paper23.pdf

Durkheim, Emile. 1995 [1912]. The Elementary Forms of Religious Life. Trans. Karen E. Fields. New York: Free Press.

Ellington, Thomas C. 2011. "Secrecy and Disclosure: Policies and Consequences in the American Experience." In Research in Social Problems and Public Policy, Volume 19: Government Secrecy, edited by Susan Maret, 67-90. Bingley, UK: Emerald Group.

Ellsberg, Daniel. 2002. Secrets: A Memoir of Vietnam and the Pentagon Papers. New York: Penguin.

Ericson, Timothy L. 2005. "Building Our Own" Iron Curtain": The Emergence of Secrecy in American Government." The American Archivist 68, no. 1: 18-52.

http://americanarchivist.org/doi/pdf/10.17723/aarc.68.1.9m260j24417 7p553? code=same-site

Evans, Samuel A. W., and Walter D. Valdivia. 2012. "Export Controls and the Tensions Between Academic Freedom and National Security." Minerva 50, no. 2: 169-90.

Gieryn, Thomas F. 1983. "Boundary-Work and the Demarcation of Science from Non-Science: Strains and Interests in Professional Ideologies of Scientists." American Sociological Review 48, no. 6: 781-95.

Gusterson, Hugh. 1996. Nuclear Rites: A Weapons Laboratory at the End of the Cold War. Berkeley: University of California Press. 
. 1999. "Secrecy, Authorship and Nuclear Weapons Scientists." In Secrecy and Knowledge Production. Occasional Paper No. 23, edited by Judith Reppy, 57-75. Ithaca, NY: Cornell University Peace Studies Program.

http://large.stanford.edu/publications/crime/references/dennis/occasion al-paper23.pdf

Hammersley, Martyn and Paul Atkinson. 1995. Ethnography: Principles in Practice. London: Routledge.

Hasler, Susan.2010. Intelligence: A Novel of the CIA. New York: Thomas Dunne.

Hayden, Michael. 2016. Playing to the Edge: American Intelligence in the Age of Terror. New York: Penguin.

Johnston, Rob. 2005. Analytic Culture in the U.S. Intelligence Community: An Ethnographic Study. Washington: Central Intelligence Agency Center for the Study of Intelligence. https://www.cia.gov/library/center-forthe-study-of-intelligence/csi-publications/books-andmonographs/analytic-culture-in-the-u-s-intelligencecommunity/analytic_culture_report.pdf

Jones, Abigail. 2016. "Women of the CIA: The Hidden History of American Spycraft." Newsweek, September 21. http://www.newsweek.com/2016/09/30/cia-women-national-security500312.html

Kusiak, Pauline. 2008. "Sociocultural Expertise and the Military: Beyond the Controversy." Military Review November-December: 65-76.

Lowenthal, Mark M. 2015. Intelligence: From Secrets to Policy. Thousand Oaks, CA: CQ Press.

MacKenzie, Donald and Graham Spinardi. 1995. "Tacit Knowledge, Weapons Design, and the Uninvention of Nuclear Weapons." American Journal of Sociology 101, no. 1: 44-99. 
Masco, Joseph. 2006. The Nuclear Borderlands: The Manhattan Project in Post-Cold War New Mexico. Princeton, NJ: Princeton University Press.

Masco, Joseph. 2010. "'Sensitive but Unclassified': Secrecy and the Counterterrorist State." Public Culture 22, no. 3: 433-63.

McDermott, Patrice. 2011. "Secrecy Reform or Secrecy Redux?: Access to Information in the Obama Administration." In Research in Social Problems and Public Policy, Volume 19: Government Secrecy, edited by Susan Maret, 189-218. Bingley, UK: Emerald.

Nolan, Bridget. 2013. "Information Sharing and Collaboration in the United States Intelligence Community: An Ethnographic Study of the National Counterterrorism Center." Unpublished Dissertation.

Plame, Valerie. 2007. Fair Game. New York: Simon \& Schuster.

Price, David. 2011. Weaponizing Anthropology: Social Science in the Service of the Militarized State. Oakland, CA: AK Press.

Rhodes, Richard. 1986. The Making of the Atomic Bomb. New York: Simon \& Schuster.

Rindzeviciute, Egle. 2015. "The Overflow of Secrets: The Disclosure of Soviet Repression in Museums as an Excess." Current Anthropology 56, supplement 12: S276-S285.

Russell, Charles J., and Robert G. Webster. 2005. "The Genesis of a Pandemic Influenza Virus." Cell 123, no. 3: 368-71.

Teller, Edward. 1993. "The Laboratory of the Atomic Age." Los Alamos Science, 21: 32-37. 
Vaughan, Diane. 1996. The Challenger Launch Decision: Risky Technology, Culture, and Deviance at NASA. Chicago: The University of Chicago Press.

Vogel, Kathleen M., Brian Balmer, Sam Weiss Evans, Inga Kroener, Miwao Matsumoto, and Brian Rappert. 2017. "Knowledge and Security." In The Handbook of Science and Technology Studies, edited by Ulrike Felt, Rayvon Fouche, Clark A. Miller, and Laurel Smith-Doerr, 973-1001. Cambridge, MA: MIT Press.

Wellerstein, Alex. 2008. "From Classified to Commonplace: The Trajectory of the Hydrogen Bomb Secret." Endeavour 32, no. 2: 47-52.

The White House. 2009. Executive Order 13526: Classified National Security Information. https://www.gpo.gov/fdsys/pkg/FR-2010-0105/html/E9-31418.htm 